\title{
A prospective randomized comparative study of Misoprostol and balloon tamponade using condom catheter to prevent postpartum hemorrhage at M. Y. H., Indore, India in vaginal delivered patients
}

\author{
Sumitra Yadav, Anjali Malhotra*
}

Department of Obstetrics and Gynecology, MGMMC and MYH, Indore, Madhya Pradesh, India

Received: 28 October 2018

Revised: 10 December 2018

Accepted: 29 December 2018

\author{
*Correspondence: \\ Dr. Anjali Malhotra, \\ E-mail: anjalimalhotra.mbbs@gmail.com
}

Copyright: () the author(s), publisher and licensee Medip Academy. This is an open-access article distributed under the terms of the Creative Commons Attribution Non-Commercial License, which permits unrestricted non-commercial use, distribution, and reproduction in any medium, provided the original work is properly cited.

\section{ABSTRACT}

Background: PPH is responsible for quarter of maternal deaths occurring worldwide and its incidence is increasing in developed world. According to Confidential Enquiries into Maternal and Child Health (CEMACH) report obstetric hemorrhage occurs in around3.7 per 1000 births. The objective of the study is that it was a prospective randomized comparative study of misoprostol and balloon tamponade via condom catheter to prevent postpartum hemorrhage in normal delivered patients at MYH.

Methods: A sample size of 200 normal delivered patients between age group 18 and 45 years is chosen with excessive bleeding after third stage of labour and after administration of oxytocics. These 200 patients are divided into two groups: First group receiving Misoprostol and applying condom catheter in other group. Both groups are evaluated for PPH.

Results: It was found that CG balloon condom catheter was a much better and more effective alternative in controlling PPH than Misoprostol as the failure rate with CG balloon condom catheter were much less than that with misoprostol. Due to its cost effectiveness and being easily available at primary health center and due to absence of any drug reactions and easy technique of formation makes it a better modality in controlling PPH even at PHC.

Conclusions: Patients with condom catheter in situ must show better result than patients receiving misoprostol.

Keywords: Active management of third stage of labour (AMTSL), Antepartum hemorrhage (APH), Chattisgarh balloon (CG balloon), Condom catheter (CC), Misoprostol, Oxytocics, Postpartum haemorrhage (PPH), Pregnancy induced hypertension (PIH), Sengstaken-Blakemore oesophageal catheter (SBOC)

\section{INTRODUCTION}

Postpartum hemorrhage may occur in $1-5 \%$ of deliveries in developed countries and is still the most significant cause of maternal morbidity and mortality. ${ }^{1-3}$ The WHO estimates that PPH accounts for nearly 30\% maternal deaths worldwide with an estimated 20 million cases annually. Classically, PPH has been defined as a blood loss greater than $500 \mathrm{ml}$ after a vaginal delivery and greater than $1000 \mathrm{ml}$ after a cesarean section. ${ }^{1}$ Underestimation of post-delivery blood loss is not uncommon, and is likely contributed to, at least in part, by the ability of healthy pregnant women to lose up one liter of blood acutely without a noticeable drop in hemoglobin or significant hemodynamic change. ${ }^{4,5}$

Postpartum hemorrhage may develop in patients with no risk factors; however, reported risk factors include: multiparity, operative deliveries (forceps or vacuum assisted deliveries), previous postpartum hemorrhage, antepartum hemorrhage, prolonged third stage of labor (delivery of the placenta more than 30 minutes after 
delivery of the fetus), abnormal placentation (placenta previa, accreta or increta), oxytocin use, maternal obesity, and a distended uterus (from a large baby, multifetal gestation or excessive amniotic fluid) ${ }^{6-8}$ In developed countries, the maternal mortality of such hemorrhage has been reported to be on the order of $0.1 \%$ of all deliveries. ${ }^{8}$

The aim of this study is to prevent maternal death at a primary health care center. The objective is to study the outcome among the medical method i.e. misoprostol and interventional method i.e. CC CG Balloon for preventing postpartum hemorrhage; to study the association of highrisk factors and the postpartum hemorrhage; to study the association of parity status and postpartum hemorrhage and to study the efficiency and time responsiveness of the interventions used for prevention of postpartum hemorrhage.

\section{METHODS}

It was a randomized prospective study carried out from $1^{\text {st }}$ March 2016 to $31^{\text {st }}$ August 2017 (18 months). Number of cases were 200 .

\section{Inclusion criteria}

- All the vaginal delivered patients with atonic PPH at $\mathrm{MYH}$ after active management of third stage of labour during the duration of study.

\section{Exclusion criteria}

- Rule out causes due to traumatic PPH.

- Arterial bleeding requiring exploration and ligation or angiofigureic embolization.

- Cases indicating hysterectomy or when uterine rupture is suspected.

- Non gynaecological causes like cervical cancer.
All the cases were divided into two groups: one receiving 800 microgram misoprostol per rectally/sublingually and other group receiving CC. In around 105 cases Misoprostol was used and in another 95 cases CC was used. Cases were allocated using randomization by alternately allocating the cases to Misoprostol and CC group. After AMTSL wherever Misoprostol was used, authors watched for 10 minutes for bleeding to stop but if it did not stop authors insert CC to prevent deterioration of the cases. Further, if CC fails after 30-40 minutes cases are shifted to operation theatre and planned for sequential devascularization. Further when either of the options failed i.e. even after failure of stepwise devascularisation, authors proceed for hysterectomy.

\section{RESULTS}

Table 1 showing distribution of cases with booked cases $77 \%$ and unbooked cases $23 \%$.

Table 1: Distribution of cases depending on booked and unbooked status.

\begin{tabular}{|l|l|l|}
$\begin{array}{l}\text { Registration } \\
\text { status }\end{array}$ & $\begin{array}{l}\text { Number of } \\
\text { cases }\end{array}$ & $\begin{array}{l}\text { Cases (in } \\
\text { percentage) }\end{array}$ \\
\hline Unbooked & 46 & 23 \\
\hline Booked & 154 & 77 \\
\hline Total & 200 & 100 \\
\hline
\end{tabular}

Table 2 showing distribution of cases depending upon the age group suggesting most commonly affected age group was of 21 to 25 years age group contributing to $42 \%$ of cases followed by 26 to 30 years age group contributing to $32 \%$ of cases. It is followed by age groups of 16 to 20 years $(14.5 \%), 31$ to 35 years $(9 \%)$, and lastly $>35$ years $(2.5 \%)$. Modality of treatment used suggests most commonly used is CC i.e. in $61 \%$ cases and misoprostol in $52.5 \%$ cases. However, Misoprostol failed in around $13.5 \%$ cases and hysterectomy was done in around $2.5 \%$ cases.

Table 2: Distribution of cases depending upon the age group and modality of treatment used.

\begin{tabular}{|c|c|c|c|c|c|c|}
\hline $\begin{array}{l}\text { Age group (in } \\
\text { years) }\end{array}$ & $\begin{array}{l}\text { Misoprostol } \\
\text { cases }\end{array}$ & $\begin{array}{l}\text { Misoprostol } \\
\text { failure cases }\end{array}$ & $\begin{array}{l}\mathrm{CC} \\
\text { cases }\end{array}$ & $\begin{array}{l}\text { Hysterectomy } \\
\text { cases }\end{array}$ & $\begin{array}{l}\text { Total } \\
\text { cases }\end{array}$ & $\begin{array}{l}\text { Cases (in } \\
\text { percentage) }\end{array}$ \\
\hline $16-20$ & 15 & 4 & 18 & 1 & 29 & 14.5 \\
\hline $21-25$ & 49 & 12 & 47 & 2 & 84 & 42 \\
\hline $25-30$ & 25 & 4 & 43 & 1 & 64 & 32 \\
\hline $31-35$ & 11 & 6 & 13 & 1 & 18 & 9 \\
\hline$>35$ & 5 & 1 & 1 & 0 & 5 & 2.5 \\
\hline Total & 105 & 27 & 122 & 5 & 200 & 100 \\
\hline
\end{tabular}

Table 3 showing distribution of cases depending upon parity status; most commonly affected were third gravida group contributing $35 \%$ cases followed by second gravida $24 \%$ cases and primi gravida and more than or equal to four gravida contributing $29.5 \%$ and $11.5 \%$ cases, respectively. The parity status with most common being third gravida group with 34 cases managed using Misoprostol and 47 cases managed using $\mathrm{CC}$ and 2 cases 
underwent hysterectomy because of failure of either method.
However, 3 cases underwent hysterectomy among primigravida after failure of either method.

Table 3: Distribution of cases depending upon the parity and the respective modality of treatment used.

\begin{tabular}{|c|c|c|c|c|c|c|}
\hline $\begin{array}{l}\text { Parity } \\
\text { status }\end{array}$ & $\begin{array}{l}\text { Misoprostol } \\
\text { cases }\end{array}$ & $\begin{array}{l}\text { Misoprostol } \\
\text { failure cases }\end{array}$ & $\begin{array}{l}\mathrm{CC} \\
\text { cases }\end{array}$ & $\begin{array}{l}\text { Hysterectomy } \\
\text { cases }\end{array}$ & $\begin{array}{l}\text { Total } \\
\text { cases }\end{array}$ & $\begin{array}{l}\text { Cases (in } \\
\text { percentage) }\end{array}$ \\
\hline 1 & 24 & 7 & 42 & 3 & 59 & 29.5 \\
\hline 2 & 29 & 4 & 23 & 0 & 48 & 24 \\
\hline 3 & 34 & 11 & 47 & 2 & 70 & 35 \\
\hline$>4$ & 18 & 5 & 10 & 0 & 23 & 11.5 \\
\hline Total & 105 & 27 & 122 & 5 & 200 & 100 \\
\hline
\end{tabular}

Table 4: Distribution of cases depending upon pregnancy outcome and modality of treatment used.

\begin{tabular}{|c|c|c|c|c|c|c|}
\hline $\begin{array}{l}\text { Pregnancy } \\
\text { status }\end{array}$ & $\begin{array}{l}\text { Misoprostol } \\
\text { cases }\end{array}$ & $\begin{array}{l}\text { Misoprostol } \\
\text { failure cases }\end{array}$ & CC cases & $\begin{array}{l}\text { Hysterectomy } \\
\text { cases }\end{array}$ & $\begin{array}{l}\text { Total } \\
\text { cases }\end{array}$ & $\begin{array}{l}\text { Cases (in } \\
\text { percentage) }\end{array}$ \\
\hline Preterm & 25 & 3 & 18 & 1 & 40 & 20 \\
\hline Term & 58 & 10 & 70 & 4 & 118 & 59 \\
\hline Post term & 9 & 2 & 13 & 0 & 20 & 10 \\
\hline Postnatal & 13 & 12 & 21 & 0 & 22 & 11 \\
\hline Total & 105 & 27 & 122 & 5 & 200 & 100 \\
\hline
\end{tabular}

Table 5: Distribution of cases depending on associated high-risk factor and procedure used.

\begin{tabular}{|c|c|c|c|c|c|c|}
\hline Associated high risk factors & $\begin{array}{l}\text { Misoprostol } \\
\text { cases }\end{array}$ & $\begin{array}{l}\text { Misoprostol } \\
\text { failure cases }\end{array}$ & $\begin{array}{l}\mathrm{CC} \\
\text { cases }\end{array}$ & $\begin{array}{l}\text { Hysterectomy } \\
\text { cases }\end{array}$ & $\begin{array}{l}\text { Total } \\
\text { cases }\end{array}$ & $\begin{array}{l}\text { Cases (in } \\
\text { percentage) }\end{array}$ \\
\hline Anemia & 20 & 7 & 35 & 0 & 48 & 24 \\
\hline Jaundice & 9 & 4 & 8 & 1 & 13 & 6.5 \\
\hline Pregnancy induced hypertension & 17 & 7 & 26 & 2 & 36 & 18 \\
\hline Antepartum hemorrhage & 10 & 3 & 18 & 1 & 25 & 12.5 \\
\hline Obstructed labour & 7 & 3 & 4 & 1 & 8 & 4 \\
\hline Amniotic fluid disorders & 14 & 0 & 7 & 0 & 21 & 10.5 \\
\hline Twins & 2 & 2 & 5 & 1 & 5 & 2.5 \\
\hline Atonic PPH & 2 & 2 & 3 & 0 & 3 & 1 \\
\hline Uterine inversion & 0 & 0 & 2 & 0 & 2 & 1.5 \\
\hline No high-risk factor & 25 & 0 & 16 & 0 & 41 & 20.5 \\
\hline Total & 106 & 28 & 124 & 6 & 202 & 100 \\
\hline
\end{tabular}

Some cases may belong to superimposed category.

Table 4 showing distribution of cases depending upon the pregnancy outcome with most cases belonging to category of Term pregnancy $(59 \%)$ followed by preterm pregnancy $(20 \%)$, postnatal cases $(11 \%)$ and post term pregnancy $(10 \%)$. And modality of treatment used with $35 \%$ of the cases of term pregnancy managed using CC and around $26 \%$ of the cases managed using Misoprostol. However, with failure of either method Hysterectomy was done in $2 \%$ cases.

Table 5 showing distribution of cases depending on associated high-risk factor and procedure used with most cases of Anemia nearly 48 (24\%) cases followed by no high-risk factors i.e. $20.5 \%$ cases. The CC controlled
PPH in 35 cases with Anemia, 26 cases with PIH and 18 cases with APH.

Table 6: Distribution of cases depending on intervention used.

\begin{tabular}{|l|l|l|}
\hline Procedure used & $\begin{array}{l}\text { Number of } \\
\text { cases in which } \\
\text { procedure was } \\
\text { unsuccessful }\end{array}$ & $\begin{array}{l}\text { Number of } \\
\text { cases in which } \\
\text { procedure } \\
\text { was successful }\end{array}$ \\
\hline Misoprostol & 27 & 78 \\
\hline CC & 5 & 117 \\
\hline Hysterectomy & 0 & 5 \\
\hline Total & 32 & 200 \\
\hline
\end{tabular}

Some cases may belong to superimposed category. 
Table 6 showing distribution of cases depending on intervention used; The Pearson chi square test was applied to see the association between whether PPH was controlled and the procedure used to do so. The value of this test was 47.028 and $p$ value for this was 0.00 which was found to be clinically significant as $\mathrm{p}$ value is less than 0.05. Misoprostol was used successfully in $36 \%$ cases and CC was used successfully in $56.5 \%$ but misoprostol failed in $13.5 \%$ cases and CC failed in $2.5 \%$ cases.

Table 7 showing Fischer's exact test was applied to see the association between PPH controlled and the high-risk factor associated with it. The $\mathrm{p}$ value for Fischer's exact test was 0.000 and this is less than 0.05 hence found to be clinically significant. Thus, there is positive association between PPH controlled and the associated high-risk factor.

Table 7: Distribution of cases showing association of high-risk factors and PPH was controlled or not.

\begin{tabular}{|l|l|l|l|}
\hline $\begin{array}{l}\text { Associated high } \\
\text { risk factors }\end{array}$ & $\begin{array}{l}\text { PPH } \\
\text { controlled }\end{array}$ & $\begin{array}{l}\text { PPH not } \\
\text { controlled }\end{array}$ & $\begin{array}{l}\text { Total } \\
\text { cases }\end{array}$ \\
\hline Anemia & 41 & 7 & 48 \\
\hline $\begin{array}{l}\text { Jaundice } \\
\begin{array}{l}\text { Pregnancy induced } \\
\text { hypertension }\end{array}\end{array}$ & 9 & 4 & 13 \\
\hline $\begin{array}{l}\text { Antepartum } \\
\text { hemorrhage }\end{array}$ & 22 & 7 & 36 \\
\hline \begin{tabular}{l} 
Obstructed labour \\
\hline Uterine inversion
\end{tabular} & 5 & 3 & 25 \\
\hline $\begin{array}{l}\text { Amniotic fluid } \\
\text { disorders }\end{array}$ & 21 & 3 & 8 \\
\hline Twins & 4 & 0 & 2 \\
\hline Atonic PPH & 3 & 0 & 21 \\
\hline No high factors & 41 & 0 & 5 \\
\hline Total & 175 & 27 & 3 \\
\hline
\end{tabular}

Some cases may belong to superimposed category.

Table 8 showing distribution of cases according to booking status and modality of treatment used. The Fischer's Exact test was applied to see the association between PPH controlled and the Booking status of the cases. The $\mathrm{p}$ value for the test was 0.047 and it is less than 0.05 which is found to be clinically significant.

Table 8: Distribution of cases according to booking status and modality of treatment used.

\begin{tabular}{|l|l|l|}
\hline Intervention used & $\begin{array}{l}\text { Number of } \\
\text { booked cases }\end{array}$ & $\begin{array}{l}\text { Number of } \\
\text { unbooked cases }\end{array}$ \\
\hline Misoprostol cases & 87 & 18 \\
\hline $\begin{array}{l}\text { Misoprostol failure } \\
\text { cases }\end{array}$ & 25 & 7 \\
\hline CC cases & 92 & 30 \\
\hline Hysterectomy cases & 0 & 5 \\
\hline Total & 204 & 55 \\
\hline
\end{tabular}

Table 9 showing independent $\mathrm{t}$ tests were applied and it was observed that the PPH to CG balloon interval, CG balloon inflation to hemostasis interval and hemostasis interval was found to be significant with the $\mathrm{p}$ value of $0.000(<0.05)$. Thus, whether PPH is controlled or not is affected by the hemostasis interval, PPH to CG balloon Insertion interval and $\mathrm{CG}$ balloon inflation to hemostasis interval.

Table 9: Comparison of hemostasis interval between cases in whom PPH was controlled or not.

\begin{tabular}{|l|l|l|}
\hline Outcome & $\begin{array}{l}\text { Cases in which } \\
\text { PPH was } \\
\text { controlled }\end{array}$ & $\begin{array}{l}\text { Cases in which } \\
\text { PPH was not } \\
\text { controlled }\end{array}$ \\
\hline $\begin{array}{l}\text { PPH to CG balloon } \\
\text { insertion interval }\end{array}$ & 8.07 & 17.07 \\
\hline $\begin{array}{l}\text { CG balloon } \\
\text { inflation to } \\
\text { hemostasis interval }\end{array}$ & 7.13 & 15.32 \\
\hline $\begin{array}{l}\text { Hemostasis interval } \\
\text { (in minutes) }\end{array}$ & 12.69 & 22.96 \\
\hline
\end{tabular}

Table 10 showing distribution of cases receiving blood transfusion; $53 \%$ cases received blood transfusion while $47 \%$ cases did not receive blood transfusion.

Table 10: Distribution of cases receiving blood transfusion.

\begin{tabular}{|l|l|l|}
\hline $\begin{array}{l}\text { Blood } \\
\text { components }\end{array}$ & $\begin{array}{l}\text { Number of } \\
\text { cases }\end{array}$ & $\begin{array}{l}\text { Percentage of } \\
\text { cases }\end{array}$ \\
\hline Transfused & 106 & 53 \\
\hline Not transfused & 94 & 47 \\
\hline Total & 200 & 100 \\
\hline
\end{tabular}

Table 11 showing quantification of amount of blood loss on whether PPH was controlled or not; The amount of blood loss affects whether PPH was controlled or not. Independent $t$ test was applied, and its $\mathrm{p}$ value was 0.000 $(<0.05)$ which is found to be significant.

Table 11: Quantification of amount of blood loss on whether PPH was controlled or not.

\begin{tabular}{|l|l|l|}
\hline Outcome & $\begin{array}{l}\text { Amount of blood } \\
\text { loss (in milliliter) }\end{array}$ & $\begin{array}{l}\text { Number of } \\
\text { cases }\end{array}$ \\
\hline $\begin{array}{l}\text { PPH was } \\
\text { controlled }\end{array}$ & 663.80 & 173 \\
\hline $\begin{array}{l}\text { PPH was not } \\
\text { controlled }\end{array}$ & 1100.00 & 27 \\
\hline
\end{tabular}

\section{DISCUSSION}

The mean age group in present study was $25.27 \pm 4.636$ years. Out of total of 200 cases, $48 \%$ cases belong to age group of 21 to 25 years of age, $14.5 \%$ cases in the age group of 17 to 20 years, $32 \%$ cases in age group of 26-30 years, $9 \%$ cases in the age group of 31 to 35 years and $2.5 \%$ cases in the age group of $>35$ years. However, age 
has no significant association with whether $\mathrm{PPH}$ is controlled or not as $\mathrm{p}$ value is $0.334(>0.05)$.

In study by Tort $\mathbf{J}$ et al, Parity status is found to be nonsignificant w.r.t PPH. ${ }^{9}$ Also pregnancy status is found to be non-significant w.r.t PPH. However, in present study, Pregnancy status affects the outcome i.e. whether PPH is controlled or not. In my study most of the cases belong to third gravida status i.e. $35 \%$ cases followed by primi gravida i.e. $29.5 \%$ cases, second gravida cases being $24 \%$ cases, and lastly four and more gravida included $11.5 \%$ cases. However, study conducted by Gurung BS, et al showed parity ranged from $1-4$, with a median of $2 .{ }^{10}$ In present study, $48(24 \%)$ cases belong to category of anemia and $25(12.5 \%)$ cases belong to category of APH, however, in the study conducted by Parpillewar MB et al included $13.8 \%$ cases with anemia and $22.22 \%$ with APH. ${ }^{11}$ Moreover, in study by Mishra $\mathrm{N}$ et al, primi and para two women were five each and remaining three were para three. ${ }^{12}$

In present study the mean amount of blood loss is $663.80 \mathrm{ml}$ in the cases in which PPH was controlled i.e. in $86.5 \%$ cases and $1100.00 \mathrm{ml}$ in the cases in which PPH was not controlled i.e. $13.5 \%$ cases. The minimum amount of blood loss was $400 \mathrm{ml}$ and the maximum was $1500 \mathrm{ml}$. In study by Sheikh $\mathrm{L}$ et al, the mean blood loss was $2431 \pm 1817 \mathrm{ml}$ (range: $1500-9000 \mathrm{ml}$ while in study by Tort $\mathrm{J}$ et al, the mean amount of blood loss is $800 \mathrm{ml}$ and in the study conducted by Martin et al, the mean blood loss before putting CC was $1343 \pm 223 \mathrm{ml}$ while mean blood loss after condom balloon insertion was $308 \pm 83.42 \mathrm{ml} .{ }^{9,13,14}$ Mean comparison of blood loss before and after condom balloon insertion was done and found to be statistically significant $(\mathrm{p}<0.001)$. The same result was found in my study that the PPH to CG balloon interval, CG Balloon inflation to hemostasis interval and Hemostasis interval was found to be significant with the $p$ value of 0.00 which is less than 0.05 and was found to be significant. In study by Thapa $\mathrm{K}$ et al, CC was applied to fourteen cases with varying degrees of $\mathrm{PPH}$, not controlled with pharmacologic measures. ${ }^{15}$ Average amount of blood loss was $1221 \mathrm{ml}$ and it was $1480 \mathrm{ml}$ in study conducted by Ahmad SN et al. ${ }^{16}$ In a study of case series by Mishra $\mathrm{N}$ et al, the mean blood loss was $1611 \mathrm{ml}^{12}$

In the study by Ahmad SN et al, the mean time taken to arrest bleeding after the application of the $\mathrm{CC}$ was 6.66 minutes. ${ }^{16}$ In my study the mean Hemostasis interval in $86.5 \%$ cases with PPH controlled was 12.69 minutes and the $13.5 \%$ cases in with PPH not controlled was 22.96 minutes. In the latter group, $2.5 \%$ cases ended in hysterectomy. In study of case series by Mishra $\mathrm{N}$ et al, the mean time interval between the diagnosis of atonic $\mathrm{PPH}$ and introduction of $\mathrm{CC}$ was 19.6 min. ${ }^{12}$ In a study of case series by Mishra $\mathrm{N}$ et al, control of $\mathrm{PPH}$ was achieved in 12 cases in the mean time of $12.6 \mathrm{~min} .{ }^{12}$ In study by Doumouchtsis SK et al, in cases where the balloon was successful it was removed around 24 hours late. ${ }^{17}$ The mean duration for which $\mathrm{CC}$ was left in situ was 27.5 hours. In study by Tort $\mathrm{J}$ et al, the average time during which the $\mathrm{CC}$ was left in place was 9 hours 11 minutes. ${ }^{9}$

In present study, the mean time for which $\mathrm{CC}$ in situ with PPH controlled was 22.67 hours and PPH not controlled was 24.67 hours. Minimum and maximum duration for which $C$ in situ was 2 hours and 48 hours respectively. In study by Moushmi B et al, the average duration for $\mathrm{CC}$ in situ was 30 hours 14 minutes. ${ }^{11}$ The $\mathrm{CC}$ in situ for a mean duration of $19.94 \pm 3.84$ hours in the study by Ahmad SN et al. ${ }^{16}$ Minimum duration for keeping CC in situ was 13 hours and the maximum was 24 hours. In a study of case series by Mishra $\mathrm{N}$ et al, $\mathrm{CC}$ in situ for at least 12-24 hours. $^{12}$

In present study, the mean amount of fluid inflated in CG balloon was $416.84 \mathrm{ml}$ in 95 cases and $418.18 \mathrm{ml}$ in 22 cases respectively in cases with PPH controlled and not controlled. However, the minimum amount of fluid inflated in CG balloon was $200 \mathrm{ml}$ and the maximum was $600 \mathrm{ml}$. In study conducted by Tort $\mathrm{J}$ et al, the average fill volume was $443.3 \mathrm{ml} .{ }^{9}$ However, the mean volume of fluid used to create tamponade was $381.06 \mathrm{ml}$ in the study by Ahmad SN et al. ${ }^{16}$

In the study conducted by Martin $\mathrm{E}$ et al, uterine tamponade was used in 49 women; $61 \%$ after vaginal delivery and $39 \%$ after cesarean section. ${ }^{14}$ The overall success rate was $65 \%$. Of 17 failures, surgery was required in 16 cases, including hysterectomy in 11 , and uterine artery embolization in one case while in study by Sheikh L et al, Cesarean hysterectomy done in 3 cases. ${ }^{13}$ However, In study by Ahmad SN et al CC successfully controlled haemorrhage in 31 out of 33 patients. ${ }^{16}$ In both the failed cases, hysterectomy was required $(6 \%)$. However, in my study CC controlled PPH in 95 cases including 27 cases with Misoprostol failure and it failed in 5 cases for which hysterectomy was done.

In study by Moushmi B et al, CC inserted in 23 cases. $^{11}$ Out of these cases, 18 were successful without further intervention. 5 cases had failure and in 4 cases abdomen was opened, devascularisation was carried out and only 1 case responded. In remaining 3 cases hysterectomy had to be done.

In study by Doumouchtsis SK et al, there were 27 women who had placement of the SBOC. ${ }^{17}$ In 22 cases hemostasis was achieved, while in 5 cases the SBOC failed in arresting hemorrhage and hysterectomy was done. In study by Majumdar A et al, 22 cases in which the Rusch balloon was used to control massive PPH. ${ }^{18}$ Out of 22 cases, 13 cases required no further interventions after balloon tamponade and 7 cases underwent hysterectomy. However, in study by Kong MC et al, out of 35 cases, there were 19 cases in whom the Bakri balloon catheter was used. ${ }^{19}$ Within the same period, 
there were 6 peripartum hysterectomies, 2 of which involved attempted use of the Bakri balloon catheter.

\section{CONCLUSION}

Outcome is affected by the booking status of cases. Age has no significant association with whether $\mathrm{PPH}$ is controlled or not. Parity status does not affect whether $\mathrm{PPH}$ is controlled or not. Outcome is significantly affected by the hemostasis interval, PPH to CG balloon insertion interval and CG balloon inflation to hemostasis interval. CC was found to be more cost effective, being cheaper and easily available at primary health care centre. Misoprostol can be misused for MTP and unwanted pregnancies, so we can aptly use $\mathrm{CC}$ for saving life.

\section{Funding: No funding sources}

Conflict of interest: None declared

Ethical approval: The study was approved by the Institutional Ethics Committee

\section{REFERENCES}

1. Pritchard JA, Baldwin RM, Dickey JC, Wiggins KM. Blood volume changes in pregnancy and the puerperium: 2. Red blood cell loss and changes in apparent blood volume during and following vaginal delivery cesarean section and cesarean section plus total hysterectomy. Am J Obstet Gynecol. 1962;84(10):1271-82.

2. Hofmeyr GJ, Mohlala BK. Hypovolaemic shock. Bailleres Best Pract Res Clin Obstet Gynaecol. 15:645-62.

3. Abou Zahr C, Royston E. Global Mortality: Global Factbook. 1991, Geneva: World Health Organisation.

4. Stones RW, Paterson CM, Saunders NJ. Risk factors for major obstetric haemorrhage. Europ J Obstet Gynecol Reprod Biol. 1993;48:15-8.

5. American College of Obstetrics and Gynecology practice bulletin: Clinical Management Guidelines for Obstetricians-Gynecologists number 76, October 2006: Postpartum Hemorrhage. Obstet Gynecol. 2006; 108:1039-47.

6. Combs CA, Murphy EL, Laros RK. Factors associated with postpartum hemorrhage with vaginal birth. Obstet Gynecol. 1991;77:69-76.

7. Prasertcharoensuk W, Swadpanich U, Lumbiganon P. Accuracy of the blood loss estimation in the third stage of labor. Int J Gynaecol Obstet. 2000;71:69-70.

8. Tsu VD. Postpartum haemorrhage in Zimbabwe: a risk factor analysis. Brit J Obstet Gynaecol. 1993;100:327-33.

9. Tort J, Hounkpatin B, Popowski T, Traore M, Bodin $\mathrm{C}$, Perrin R, et al. A randomized controlled trial to test the effectiveness of intrauterine balloon tamponade with condom catheter in severe postpartum hemorrhage management: a feasibility study in Benin. J Women's Health Care. 2013;2:135.

10. Gurung BS, Dongol Y, Tuladhar H. Condom tamponade in the management of massive obstetric hemorrhage: an experience at a teaching hospital. Nepal J Obstet Gynaecol. 2014;9(1):41-7.

11. Parpillewar MB, Fusey SS. Intrauterine condom catheter tamponade in the management of atonic postpartum haemorrhage: a case series from a tertiary care centre in Central India. Int J Reprod Contracept Obstet Gynecol. 2017;6(8):3468-72.

12. Mishra N, Agrawal S, Gulabani K, Shrivastava C. Use of an innovative condom balloon tamponade in postpartum haemorrhage: a report. J Obstet Gynaecol India. 2016;66(1):63-7.

13. Sheikh L, Najmi N, Khalid U, Saleem T. Evaluation of compliance and outcomes of a management protocol for massive postpartum hemorrhage at a tertiary care hospital in Pakistan. BMC Preg Childbirth. 2011;11:28.

14. Martin E, Legendre G, Bouet PE, Cheve MT, Multon $\mathrm{O}$, Sentilhes L. Maternal outcomes after uterine balloon tamponade for postpartum hemorrhage. Acta Obstet Gynecol Scand. 2015;94(4):399-404.

15. Thapa K, Malla B, Pandey S, Amatya S. Intrauterine $\mathrm{CC}$ in management of post partum haemorrhage. $\mathrm{J}$ Nepal Health Res Counc. 2010;8(1):19-22.

16. Ahmad SN, Seth S, Agarwal S, Choudhary S. Evaluating condom catheter balloon tamponade in non-traumatic postpartum haemorrhage resistant to medical management. Int $\mathrm{J}$ Reprod Contracept Obstet Gynecol. 2017;5(6):1874-8.

17. Doumouchtsis SK, Papageorghiou AT, Arulkumaran S. Systematic review of conservative management of postpartum hemorrhage: what to do when medical treatment fails. Obstet Gynecol Surv. 2007;62:540-7.

18. Balloon tamponade for postpartum haemorrhage: case series and literature review. Available at: https://ncbi.nlm.nih.gov/labs/articles/23650196/

19. Maternal outcomes after uterine balloon tamponade for postpartum hemorrhage. Available at: https://ncbi.nlm.nih.gov/labs/articles/25604036.

Cite this article as: Yadav S, Malhotra A. A prospective randomized comparative study of Misoprostol and balloon tamponade using condom catheter to prevent postpartum hemorrhage at M. Y. $\mathrm{H}$., Indore, India in vaginal delivered patients. Int $\mathrm{J}$ Reprod Contracept Obstet Gynecol 2019;8:591-6. 